\title{
Article \\ New Insight into the Identity of Italian Grapevine Varieties: The Case Study of Calabrian Germplasm
}

\author{
Valentina Fanelli ${ }^{1, *(D)}$, Vincenzo Roseti ${ }^{1, *}$, Michele Antonio Savoia ${ }^{1}\left(\mathbb{D}\right.$, Monica Marilena Miazzi ${ }^{1}$, \\ Pasquale Venerito ${ }^{2}$, Vito Nicola Savino ${ }^{2}$, Costantino Pirolo ${ }^{3}$, Pierfederico La Notte ${ }^{4}$, Maurizio Falbo ${ }^{5}$, \\ Fabio Petrillo ${ }^{5}$ and Cinzia Montemurro ${ }^{1,3,4} \mathbb{D}$
}

1 Department of Soil, Plant and Food Sciences, University of Bari Aldo Moro, 70126 Bari, Italy; michele.savoia@uniba.it (M.A.S.); monicamarilena.miazzi@uniba.it (M.M.M.); cinzia.montemurro@uniba.it (C.M.)

2 Center for Research, Experimentation and Training in Agriculture (CRSFA) Basile Caramia, 70010 Locorotondo, Italy; pasqualevenerito@crsfa.it (P.V.); viton.savino@gmail.com (V.N.S.)

3 SINAGRI S.r.l.—Spin Off of the University of Bari Aldo Moro, 70126 Bari, Italy; costantino.pirolo@gmail.com

4 Institute for Sustainable Plant Protection, National Research Council of Italy (CNR), 70126 Bari, Italy; pierfederico.lanotte@ipsp.cnr.it

5 Azienda Regionale per lo Sviluppo dell'Agricoltura in Calabria (ARSAC), 87100 Cosenza, Italy; maurizio.falbo@arsac.calabria.it (M.F.); fabio.petrillo@arsac.calabria.it (F.P.)

* Correspondence: valentina.fanelli@uniba.it (V.F.); vincenzo.roseti@uniba.it (V.R.)

\section{check for} updates

Citation: Fanelli, V.; Roseti, V.; Savoia, M.A.; Miazzi, M.M.; Venerito, P.; Savino, V.N.; Pirolo, C.; La Notte, P.; Falbo, M.; Petrillo, F.; et al. New Insight into the Identity of Italian Grapevine Varieties: The Case Study of Calabrian Germplasm. Agronomy 2021, 11, 1538. https://doi.org/ 10.3390/agronomy11081538

Academic Editors: Carlos Miranda and Jorge Urrestarazu

Received: 14 June 2021

Accepted: 28 July 2021

Published: 31 July 2021

Publisher's Note: MDPI stays neutral with regard to jurisdictional claims in published maps and institutional affiliations.

Copyright: (c) 2021 by the authors. Licensee MDPI, Basel, Switzerland. This article is an open access article distributed under the terms and conditions of the Creative Commons Attribution (CC BY) license (https:/ / creativecommons.org/licenses/by/ $4.0 /)$.

\begin{abstract}
Calabria is a region located in Southern Italy and it is characterized by a long tradition of viticulture practices and favorable pedoclimatic conditions for grapevine cultivation. Nevertheless, less than $2 \%$ of cultivated land is dedicated to grapevine growing in Calabria. The characterization of local grapevine accessions is crucial to valorize the local and peculiar Italian products and boost the Calabrian winemaking sector. With this purpose, we performed a deep characterization of two widespread Calabrian grapevine varieties-Magliocco Dolce and Brettio Nero, of which very little is known. In particular, a genetic and morphological analysis, a berry physico-chemical and polyphenolic compositions assessment, and oenological evaluation of monovarietal wines were carried out. Our results allowed us to demonstrate that Magliocco Dolce and Brettio Nero are unique and distinct varieties with peculiar morphological and chemical characteristics and show the suitability of these two varieties in high-quality wine production. Moreover, the obtained molecular profiles will be useful for authentication and traceability purposes.
\end{abstract}

Keywords: varietal identification; microsatellite; ampelography; polyphenols; chemical composition; wine

\section{Introduction}

Calabria is a region located at the extreme south of Italy between the Ionian and the Tyrrhenian seas. It is one of the most ancient regions of Southern Italy for grape cultivation [1], being supposed as a secondary center of grapevine domestication along with Sicily [2]. Indeed, the Greek colonization strongly influenced agriculture in Southern Italy, giving Calabria and Sicily an important role for the establishment of new grapevine varieties coming from the Eastern Mediterranean Sea and for their spreading through Northern Italy and France [3]. Moreover, the Calabria region is prevalently hilly or mountainous (90\% of the territory) with a wide range of altitudes making Calabria a favorable region for growing grapes as the altitude is directly associated with environmental factors, such as temperature and humidity, that can strongly influence the wine terroir [4].

Although the long tradition of viticulture practices and the favorable pedoclimatic conditions for cultivating grapevine, as at March 2021 only 9160 ha in Calabria are cultivated with grapevine, representing less than $2 \%$ of the Calabrian cultivated area [5]. This percentage is very low compared to other Italian regions; however, an increase in Calabrian 
PDO (Protected Designated of Origin) wine production was observed in the last years, implying the intention to boost the Calabrian winemaking sector. Nine and ten Calabrian wines are designated as PDO and PGI (Protected Geographical Indication), respectively. Among the Calabrian PDO wines, Terre di Cosenza is gaining in popularity following the success achieved in some popular wine exposition such as Vinitaly. Terre di Cosenza is a relatively new entry in PDOs since it was introduced in 2011, and it includes red, white, and rose variants. According to the disciplinary of production, Terre di Cosenza red wine is produced with the variety Magliocco in a minimal percentage of $60 \%$ [6]. The name Magliocco is used to indicate two different grapevine varieties: Magliocco Dolce and Magliocco Canino. These are two of the most widespread grapevine varieties in Calabria, cultivated mainly in the provinces of Crotone, Catanzaro, and Cosenza [7].

The name Mantonico Nero was used for a long time to indicate a black variety genetically different from Mantonico Bianco [2]. The use of the same name followed by a different adjective related to the color of berry skin is used to indicate varieties sharing the same genotype with a somatic mutation affecting fruit color, as observed for some grapevine varieties [8,9]. Therefore, the name Mantonico cannot be used to indicate both, Mantonico "Bianco" and Mantonico "Nero" (standing for white and black in Italian, respectively). Consequently, the name Brettio Nero, instead of Mantonico Nero, was indicated for the recent registration of this variety into the Italian National Registry of Grape Varieties. Mantonico Nero is used as synonymous of Magliocco Dolce in the disciplinary of production of Terre di Cosenza; although a distinct genetic profile was observed for this cultivar [2,10]. Mantonico and Magliocco are used also in the production of another Calabrian PDO wine, Lamezia, whose production has increased slightly over the last two years. According to the disciplinary of production, Lamezia red wine could be produced using Magliocco variety along with other Calabrian black varieties. Lamezia Mantonico-type wine is produced with Mantonico variety in a minimal percentage of $85 \%$.

In grapevine, it is not unusual to come across varietal confusion with the occurrence of many synonymies and homonymies. To overcome this problem, over the last 10 years the research on grapevine genotyping through DNA-based analysis has increased [11-13]. Due to the great economic value of grapevine cultivation, the first draft of the grapevine genome was published in 2007 by Jaillon et al. [14] and by Velasco et al. [15] of the highly homozygous clone Pinot Noir PN40024 and highly heterozygous Pinot Noir ENTAV115 respectively. The availability of these resources and the development of next-generation sequencing techniques have also facilitated the large-scale genotyping of grape collections [16,17], the functional genomics studies [18], the marker-assisted selection plans [19,20], the transcriptomic analyses [21], and the development of genome walking methods [22].

Grapevine genetic diversity can be assessed through ampelographic and molecular characterization; these methods are useful to identify and study local cultivars and reveal cases of synonymy and homonymy. For a long time, ampelography has been the only technique used for grapevine characterization [23]; however, it is strongly affected by the operator's experience. The "Organisation Internationale de la Vigne et du Vin" (OIV) set a list of descriptors in order to standardize the ampelographic evaluation among different operators [24]. Nevertheless, the morphological traits are influenced by several factors including environmental conditions, thus ampelography has been gradually integrated by molecular techniques that are highly reliable and reproducible since they are not influenced by environmental factors [25]. The most used molecular markers are Single Sequence Repeat (SSR) and Single Nucleotide Polymorphism (SNP) because they have a codominant nature, a high degree of polymorphism, and are distributed across the whole genome [26].

The molecular characterization of local and peculiar accessions is fundamental also for traceability and authentication purposes. Being a high-value product, wine is subjected to different kinds of fraud, such as the addition of coloring and flavoring substances, the use of undeclared varieties and mislabeling. Among the different analytical approaches used for food traceability and authentication, the isotopic ratio-based methods, the mass spectrometry, and the nuclear magnetic resonance (NMR) are the most used in wine surveil- 
lance [27]. All these methods have been proven to be highly efficient in the identification of the geographical origin and detection of adulterants added to a product; however, they present remarkable limitations in the detection of contaminant species or variety. Conversely, molecular marker-based traceability allows the univocal identification of a specific variety making possible the authentication and traceability of wine products [28].

Many studies about the grapevine genetic diversity were performed about the authentication of Calabrian varieties [2,29-31], allowing to unravel several cases of misnaming. As for Magliocco Dolce and Brettio Nero varieties, the identification remains unsolved. Pellerone et al. [29] obtained SSR profiles of variety Magliocco Canino, highlighting a genetic similarity to variety Perricone. Afterward, several synonymies for both Magliocco Dolce and Magliocco Canino were identified [11,30]; among these, a synonymy between Magliocco and Notardomenico, a variety commonly used in the production of several Apulian PGI wines, was identified. More recently, Sunseri et al. [2] affirmed that Magliocco Dolce is synonymous of Greco Nero, a variety widely cultivated in Southern Italy and used in many Calabrian PDO and PGI wines production. About the variety Mantonico, which indicates two color variants, white (Bianco) and black (Nero), only a few studies were performed to clarify the identity of this cultivar $[2,10]$.

In our study, we intended to carry out a deep study through a multidisciplinary approach about the varieties Magliocco Dolce and Brettio Nero to define their main characteristics, as these two varieties were recently registered into the Italian National Registry of Grape Varieties (INRGV) [32] and the available information about them was limited. Genetic analysis, ampelographic evaluation, berry chemical, and polyphenolic assessment were used in the past with the purpose to characterize and valorize local and peculiar Italian grapevine varieties [11,33-35]; however, this is the first time that a combined approach based on a multidisciplinary analysis is used to deeply characterize and valorize two local varieties. In detail, we verified if Magliocco Dolce and Brettio Nero were unique and distinct varieties and if they were synonymous of any other Italian variety. We evaluated several ampelographic characters related to shoot, leaf, bunch, and berry. Moreover, we measured some chemical and polyphenolic compounds in berries at maturity assessing the effect of their levels on chemical and polyphenolic composition and sensory characteristics of monovarietal red wine. In addition, a genetic analysis of different Calabrian and Italian accessions was performed, comparing the obtained molecular profiles with those available in the Italian Vitis Database (IVD) [36], INRGV [32], and the European Vitis Database (EVD) [37] with the purpose to clarify the correct denomination of different neglected Calabrian varieties. The ultimate goal was the valorization of these two local grapevine varieties through a deep definition of their main characteristics and their oenological properties and the production of a molecular profile useful for their traceability and the protection of their identity.

\section{Materials and Methods}

\subsection{Plant Material}

Fresh leaves of Magliocco Dolce, Brettio Nero, Greco Nero, and Guarnaccia Bianca provided by Agenzia Regionale per lo Sviluppo dell'Agricoltura in Calabria (ARSAC) were used for genetic analysis. In addition, 60 Italian grape genotypes sampled in different areas of Italy were also included in the analysis (Table 1). Among these, 24 samples were collected in Calabria region, and 36 were sampled in other Italian regions. In addition, morphological evaluation was performed on 50 plants for each accession, Magliocco Dolce and Brettio Nero, in four different localities of Cosenza province: Saracena, Bisignano, San Marco Argentano and Cosenza (district Donnici). Finally, chemical characterization and polyphenolic content evaluation of berries were conducted on 24 plants for each accession. 
Table 1. List of accessions used for genetic diversity analysis. Sixty-four accessions were sampled in different Italian regions, while the profile of 33 varieties was retrieved from 3 molecular grapevine databases (INRGV = Italian National Registry of Grape Varieties; IVD = Italian Vitis Database; EVD = European Vitis Database).

\begin{tabular}{|c|c|c|c|}
\hline Accession & Sampling Region & Accession & $\begin{array}{c}\text { Database Used to Retrieve } \\
\text { the Molecular Profile }\end{array}$ \\
\hline Altamura 1 & Calabria & Aglianico del Vulture & INRGV \\
\hline Altamura 2 & Calabria & Carricante & INRGV \\
\hline Altamura 3 & Calabria & Frappato & INRGV \\
\hline Arvino & Calabria & Glera & INRGV \\
\hline Brettio Nero ARSAC & Calabria & Guarnaccia b. & INRGV \\
\hline Canino & Calabria & Lambrusco di Sorbara & INRGV \\
\hline Doraca & Calabria & Lambrusco Grasparossa & INRGV \\
\hline Greco Nero ARSAC & Calabria & Magliocco Canino & INRGV \\
\hline Guarnaccia & Calabria & Mantonico Bianco & INRGV \\
\hline Guarnaccia Bianca & Calabria & Montonico Bianco & INRGV \\
\hline Guarnaccia Bianca ARSAC & Calabria & Moscato di Scanzo & INRGV \\
\hline Guarnaccia Saracena & Calabria & Notardomenico & INRGV \\
\hline Guarnaccia Bianca-like & Calabria & Tintilia & INRGV \\
\hline Guarnaccia Nera & Calabria & Trebbiano di Soave & INRGV \\
\hline Lagrima Nera & Calabria & Trebbiano Romagnolo & INRGV \\
\hline Magliocco Dolce ARSAC & Calabria & Zibibbo & INRGV \\
\hline Magliocco Canino & Calabria & Guarnaccia Nera & IVD \\
\hline Magliocco Dolce & Calabria & Guarnaccia Bianca & IVD \\
\hline Magliocco Falvo & Calabria & Nero d'Avola & IVD \\
\hline Magliocco Sanmarco & Calabria & Aleatico & EVD \\
\hline Mantonico Nero & Calabria & Barbera & EVD \\
\hline Mantonico Bianco & Calabria & Catarratto Bianco comune & EVD \\
\hline Mantonico d'Alessandria & Calabria & Chardonnay & EVD \\
\hline Mantonico di Roggiano & Calabria & Greco & EVD \\
\hline Mantonico-like & Calabria & Falanghina & EVD \\
\hline Unknown 1 & Calabria & Fiano & EVD \\
\hline Unknown 2 & Calabria & Malvasia delle Lipari & EVD \\
\hline Unknown 3 & Calabria & Malvasia Nera & EVD \\
\hline Caldarese & Puglia & Montonico Bianco & EVD \\
\hline Bianco d'Alessano & Puglia & Nebbiolo & EVD \\
\hline Bombino Bianco & Puglia & Nerello Mascalese & EVD \\
\hline Bombino Nero & Puglia & Syrah & EVD \\
\hline Maresco & Puglia & Tempranillo & EVD \\
\hline Minutolo & Puglia & & \\
\hline Moscatello selvatico & Puglia & & \\
\hline Moscatiddone & Puglia & & \\
\hline Moscato Reale & Puglia & & \\
\hline Negroamaro & Puglia & & \\
\hline Ottavianello & Puglia & & \\
\hline Primitivo & Puglia & & \\
\hline Prunesta & Puglia & & \\
\hline San Martino & Puglia & & \\
\hline Somarello Rosso & Puglia & & \\
\hline Susumaniello & Puglia & & \\
\hline Trebbiano Toscano & Puglia & & \\
\hline Uva di Troia & Puglia & & \\
\hline Ciliegiolo & Abruzzo & & \\
\hline Gaglioppo & Abruzzo & & \\
\hline Montepulciano & Abruzzo & & \\
\hline Moscato Bianco & Abruzzo & & \\
\hline Moscato d'Alessandria & Abruzzo & & \\
\hline Moscato di Terracina & Abruzzo & & \\
\hline Mostosa & Abruzzo & & \\
\hline Malvasia & Toscana & & \\
\hline
\end{tabular}


Table 1. Cont.

\begin{tabular}{|c|c|c|c|}
\hline Accession & Sampling Region & Accession & $\begin{array}{l}\text { Database Used to Retrieve } \\
\text { the Molecular Profile }\end{array}$ \\
\hline Merlot & Toscana & & \\
\hline Moscato d'Amburgo & Toscana & & \\
\hline Pinot Nero & Toscana & & \\
\hline Sangiovese & Toscana & & \\
\hline Cabernet & Veneto & & \\
\hline Moscato Giallo & Veneto & & \\
\hline Alicante & Sicilia & & \\
\hline Perricone & Sicilia & & \\
\hline Greco Bianco & Lazio & & \\
\hline Aglianico & Basilicata & & \\
\hline
\end{tabular}

\subsection{DNA Extraction and Microsatellite Analysis}

DNA was extracted from young leaves collected in the field and stored at $-80^{\circ} \mathrm{C}$ until extraction. The extraction was carried out following the protocol of Spadoni et al. [38] Quantity and quality of extracted DNA were checked through Nano-Drop ${ }^{\mathrm{TM}}$ 2000C Spectrophotometer (Thermo Scientific, Waltham, MA, USA) and $0.8 \%$ agarose gel electrophoresis.

Samples were genotyped using a set of 12 simple sequence repeat (SSR) markers: VVS2, VVMD5, VVMD7, VVMD21, VVMD25, VVMD27, VVMD28, VVMD32, VrZAG21, VrZAG62, VrZAG64, and VrZAG79 [39-42]. Each PCR reaction was performed in a final volume of $25 \mu \mathrm{L}$ containing $50 \mathrm{ng}$ of template DNA, 1X of PCR buffer, $0.25 \mathrm{uM}$ of forward and reverse primer mix, $0.1 \mathrm{mM}$ of each $\mathrm{dNTP}$ and $1 \mathrm{U}$ of DreamTaq polymerase (Thermo Fisher, Waltham, MA, USA). The forward primer was labeled at $5^{\prime}$ end with one of the FAM, VIC, PET, and NED fluorescent dyes (Sigma-Aldrich, St. Louis, MO, USA).

The cycling program consisted of a touchdown protocol: $5 \mathrm{~min}$ of initial denaturation at $94{ }^{\circ} \mathrm{C}$, followed by 10 cycles composed by (i) denaturation at $94{ }^{\circ} \mathrm{C}$ for $45 \mathrm{~s}$; (ii) annealing at $60{ }^{\circ} \mathrm{C}$ for $45 \mathrm{~s}$, with a decrement of $0.5^{\circ} \mathrm{C}$ per cycle to reach $55^{\circ} \mathrm{C}$; and (iii) extension at $72{ }^{\circ} \mathrm{C}$ for $30 \mathrm{~s}$. Then, the annealing temperature was maintained at $54{ }^{\circ} \mathrm{C}$ for the 25 successive cycles.

Amplification products $(2 \mu \mathrm{L})$ were mixed with $14 \mu \mathrm{L}$ of formamide and $0.5 \mu \mathrm{L}$ of the GeneScan 600 LIZ size standard (Life Technologies, Carlsbad, CA, USA), and then used for capillary electrophoresis. This was performed by the ABI PRISM 3100 Genetic Analyzer (Life Technologies, Carlsbad, CA, USA) and allele sizes were assigned through the GeneMapper Software version 3.7 (Life Technologies, Carlsbad, CA, USA).

\subsection{Genetic Diversity Assessment}

The molecular profiles of Magliocco Dolce and Brettio Nero were compared with the genetic profile obtained by the other Calabrian and Italian accessions and with the molecular profiles of 33 varieties available in three different databases (Italian Vitis database, Italian National Registry of Grape Varieties and European Vitis Database) (Table 1). For each marker, the following parameters were calculated by the GENALEX software version $6.51 \mathrm{~b} 2$ [43]: number of alleles (Na), effective number of alleles (Ne), Shannon's information index (I), observed (Ho) and expected (He) heterozygosity, and fixation index (F). Moreover, the polymorphic information content (PIC) and the frequency of null alleles $(\mathrm{Nu})$ were calculated using Cervus version 3.0 [44]. Frequency-based genetic distances were calculated in order to construct an unweighted neighbor-joining dendrogram for all the grapevine accessions, using DARWIN version 6.0.010 [45].

\subsection{Morphological Evaluation and Chemical Characterization of Berries}

A set of 45 OIV descriptors was used for the observations of shoot (OIV 001, 003, 004, 007, 008, 016, 351, 352, 353), young and mature leaves (OIV 051, 053, 065, 067, 068, 070, $072,074,075,076,078,079,080,081-1,081-2,083-2,084,087)$, flower sex, bunch and berry 
characteristics (OIV 151, 152, 153, 202, 204, 206, 208, 209, 220, 223, 225, 228, 235, 236, 241, $502,503)$ and grape yield (OIV 504) [24].

Ripening curves referred to sugar concentration, $\mathrm{pH}$, and total acidity were built for both Magliocco Dolce and Brettio Nero varieties. Analysis was performed on berries collected at 4 distinct stages of ripening: beginning of veraison (E-L 35), middle veraison (E-L 36), end of veraison (E-L 37), and maturity (E-L 38). Samples were collected for three seasons (2016-2018). Moreover, the following parameters were measured in berries at maturity: total anthocyanins were measured in the skin, total flavonoids, total polyphenols, proanthocyanidins, and flavans were estimated in skin and seed, and hydroxycinnamic acids were measured in the pulp. These compounds were determined by spectrophotometric methods [46]. Analysis was performed for two seasons (2016-2017).

\subsection{Chemical and Sensorial Analysis of Wines}

Magliocco Dolce and Brettio Nero were used to produce two monovarietal red wines at the experimental wine cellar of Center for Research, Experimentation and Training in Agriculture (CRSFA) Basile Caramia (Locorotondo, Italy), through the following winemaking process. Whole grapes were refrigerated for $24 \mathrm{~h}$ at $4-6^{\circ} \mathrm{C}$, then destemmed with the addition of $8 \mathrm{~g} / \mathrm{hl}$ of potassium metabisulphite. Cryomaceration was performed for $6 \mathrm{~h}$ at $4{ }^{\circ} \mathrm{C}$ followed by natural heating of the crushed grapes up to $20^{\circ} \mathrm{C}$. Afterward, ammonia salts with thiamine $(10 \mathrm{~g} / \mathrm{hl})$ were added and yeasts were inoculated. After reaching $4-5^{\circ}$ and $9^{\circ}$ alcohol, oxygenation of the whole mass and addition of ammonia salts with thiamine $(15 \mathrm{~g} / \mathrm{hl})$ was performed. Afterward, a pressing at the complete exhaustion of sugars was carried out. The wine was subjected to static clarification at $0{ }^{\circ} \mathrm{C}$ for one week and, then, naturally heated up to $20^{\circ} \mathrm{C}$. Then, lactic acid bacteria were inoculated and malolactic fermentation was monitored. Finally, the wine was transferred with oxygenation and integrated with free $\mathrm{SO} 2$ at $25 \mathrm{mg} / \mathrm{L}$. Refinement and stabilization of the wine with controlled oxygenation were performed every 15 days.

For each of the two wines, the following physico-chemical parameters were determined: alcoholic degree, total acidity, $\mathrm{pH}$, density, dry extract, volatile acidity, ash, malic acid, tartaric acid, citric acid, glycerol, potassium and sulfates, and polyphenols (total anthocyanins, total flavonoids, total polyphenols, proanthocyanidins, and flavans). Methods of analysis used for measuring each parameter are listed in the Official Journal of the European Union C 43/01 [47]. Determination of polyphenolic compounds was performed using spectrophotometric determination as described by Di Stefano et al. [48]. Six replicates of each wine were used for analysis.

A sensorial analysis was also carried out approximately six months after bottling. Hedonic sensory evaluation of wines was performed with a panel of consumers from 18 to 65 years old who have been asked to evaluate the two wines based on 24 parameters related to their color, odor, flavor, hit in mouth, persistence and overall liking on a 10-point hedonic scale. The scale of values ranged from "extremely high" to "extremely low" corresponding to the highest and lowest scores of " 10 " and " 1 ", respectively. Consumers tasted the two samples of wines served in a glass cup adequately coded and served in a randomized order. Water was available for rinsing.

\subsection{Statistical Analysis}

The statistical significance of the data was analyzed using standard unpaired Student's $t$-test. $p<0.05$ was considered to indicate a statistically significant difference.

\section{Results}

\subsection{Genetic Diversity Analysis}

A high overall genetic diversity was observed among the 97 Italian grape accessions, supporting the effectiveness of the selected SSR markers set in discriminating among the accessions (Table 2). 
Table 2. Diversity indices of 12 SSR markers detected in a set of 97 grapevine accessions.

\begin{tabular}{cccccccccc}
\hline SSR Marker & Size Range & Na & Ne & I & Ho & He & F & PIC & F (Null) \\
\hline VVS2 & $131-155$ & 10 & 4.82 & 1.83 & 0.87 & 0.79 & -0.09 & 0.77 & -0.050 \\
VVMD5 & $225-251$ & 11 & 5.12 & 1.88 & 0.81 & 0.80 & -0.01 & 0.78 & -0.007 \\
VVMD7 & $233-263$ & 8 & 4.24 & 1.68 & 0.76 & 0.76 & 0.00 & 0.73 & 0.005 \\
VVMD21 & $228-266$ & 9 & 3.88 & 1.64 & 0.77 & 0.74 & -0.03 & 0.71 & -0.011 \\
VVMD25 & $239-269$ & 11 & 4.73 & 1.82 & 0.79 & 0.79 & -0.01 & 0.76 & -0.010 \\
VVMD27 & $174-193$ & 8 & 4.79 & 1.75 & 0.82 & 0.79 & -0.04 & 0.77 & -0.023 \\
VVMD28 & $218-270$ & 14 & 7.58 & 2.20 & 0.93 & 0.87 & -0.07 & 0.85 & -0.035 \\
VVMD32 & $241-273$ & 9 & 6.07 & 1.97 & 0.77 & 0.84 & 0.07 & 0.82 & 0.038 \\
VRZAG21 & $179-215$ & 7 & 4.07 & 1.54 & 0.82 & 0.75 & -0.09 & 0.72 & -0.049 \\
VRZAG62 & $178-204$ & 10 & 7.03 & 2.04 & 0.91 & 0.86 & -0.06 & 0.84 & -0.030 \\
VRZAG64 & $135-189$ & 11 & 5.98 & 1.94 & 0.89 & 0.83 & -0.07 & 0.81 & -0.034 \\
VRZAG79 & $236-260$ & 12 & 6.44 & 2.05 & 0.82 & 0.84 & 0.02 & 0.83 & 0.010 \\
Total & & 120 & & & & & & \\
Mean & & 10 & 5.40 & & 0.83 & 0.81 & -0.03 & 0.78 \\
Min. & & 7 & 3.88 & 1.54 & 0.76 & 0.74 & -0.09 & 0.71 & -0.050 \\
Max. & & 14 & 7.58 & 2.20 & 0.93 & 0.87 & 0.07 & 0.85 & 0.038 \\
\hline
\end{tabular}

The total number of alleles (Na) was 120, ranging from 7 at the VRZAG21 locus to 14 at the VVMD28 locus. The number of effective alleles $(\mathrm{Ne})$ ranged from 3.88 to 7.58 for VVMD21 and VVMD28 markers, respectively. Shannon's information index (I) ranged from 1.54 (VRZAG21) to 2.20 (VVMD28). The null allele frequencies were estimated lower than 0.05 for all the loci, ranging between -0.050 and 0.038 , for VVS2 and VVMD32 markers, respectively. The mean observed heterozygosity (Ho) was 0.83 and expected heterozygosity $(\mathrm{He})$ was estimated as 0.81 , determining a mean value for the fixation index $(\mathrm{F})$ of -0.03 . The efficiency of the SSR markers in distinguishing the genotypes was estimated by calculating the PIC index. This value indicated a powerful discrimination ability of markers. In fact, it ranged from 0.71 (VVMD21) and 0.85 (VVMD28) with a mean value of 0.78 .

The dendrogram constructed through the unweighted neighbor-joining method clustered the accessions in three main groups (I, II, III) (Figure 1).

Group I split into two sub-clusters (I-a and I-b) containing, respectively, 50 and 14 accessions. The cluster I-a may be in turn divided into two sub-cluster (I-a1 and I-a2). The sub-cluster I-a1 contained most of the Calabrian accessions, highlighting several cases of homonymies and synonymies (Table S1). The samples Guarnaccia and Guarnaccia Nera showed a different profile compared with Guarnaccia Nera present in the Italian Vitis database, indicating a possible case of misnaming. Mantonico Nero and Brettio Nero shared identity, showing also a high similarity with Mantonico d'Alessandria and Mantonico di Roggiano. The samples named Guarnaccia Bianca and Guarnaccia Bianca-like clustered with the Guarnaccia Bianca registered into the Italian Vitis database but differed from Guarnaccia Bianca present in the Italian National Registry of Grape Varieties. A similar discrepancy was observed for the variety Montonico Bianco in the Italian National Registry of Grape Varieties and the European Vitis database, located in cluster I-b and sub-cluster I-a2, respectively. The accession Greco Nero provided by ARSAC showed a different profile compared with Greco Bianco indicating misuse of the same name followed by "Bianco" and "Nero" designation to indicate different varieties.

The sub-cluster I-a2 consisted mostly of profiles retrieved from the molecular databases corresponding to accessions cultivated in different Italian regions and included the Calabrian accessions Canino and Altamura 2. 


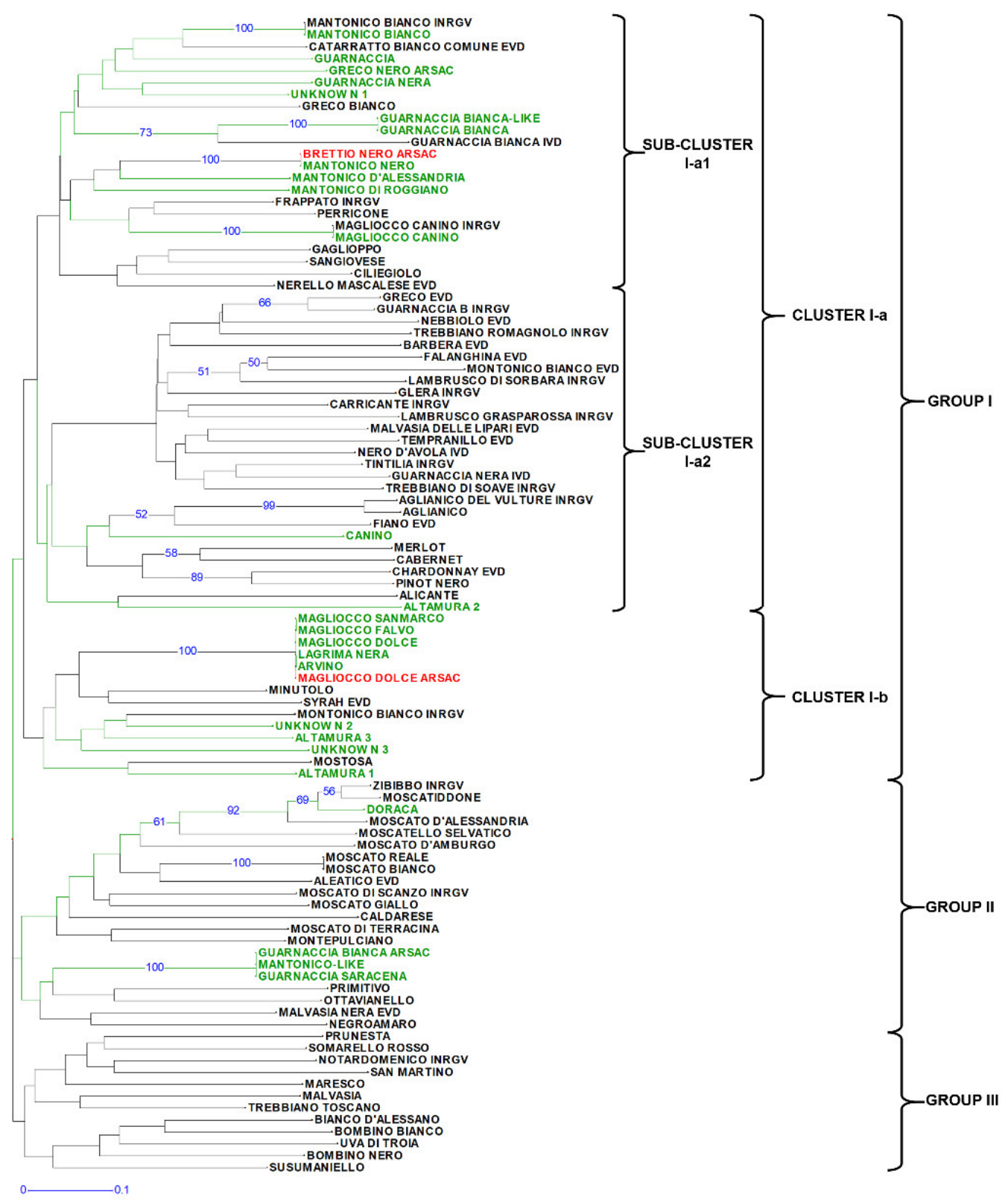

Figure 1. Unweighted neighbor-joining dendrogram obtained with SSR data from 64 grape accessions and 33 molecular profiles taken from three different grapevine databases (Italian National Registry of Grape Varieties, Italian Vitis Database and European Vitis Database). Samples collected in the Calabria region are green. Brettio Nero and Magliocco Dolce provided by ARSAC are in red.

The cluster I-b contained several Calabrian accessions. Arvino, Lagrima Nera, and Magliocco Dolce shared the same molecular profile indicating a case of synonymy. Their profile is completely different compared to that of Greco Nero provided by ARSAC.

Group II consisted of 21 samples collected in different Italian regions, including several members of the "Moscato family". Among these, Moscato Reale and Moscato Bianco represent a case of synonymy (Table S1). The samples named Guarnaccia Saracena and Mantonico-like shared the same molecular profile of Guarnaccia Bianca provided by ARSAC and they are different from both Guarnaccia Bianca retrieved in the Italian National Registry of Grape Varieties and Italian Vitis database. Finally, group III contained 12 samples and included most of the Apulian accessions.

To verify the profile of Greco Nero, Guarnaccia Bianca, Magliocco Dolce, and Brettio Nero provided by ARSAC, we checked it into the Vitis International Variety Catalogue 
(VIVC) [49]. For Magliocco Dolce and Brettio Nero, the molecular profile was identical to the one obtained in our study. The VIVC profile of Guarnaccia Bianca was different from the other profiles of Guarnaccia Bianca and the VIVC profile of Greco Nero was different from both Greco Nero ARSAC and Greco Bianco indicating a widespread confusion on the identity of these two varieties (Table S2).

\subsection{Ampelographic Characterization and Chemical Analysis of Berries}

The phenotypic profile of Magliocco Dolce and Brettio Nero based on 45 OIV descriptors was developed (Table 3). The two accessions exhibited very similar phenotypes, with some differences in mature leaf characters (OIV code 070, 072, and 079) and berry length and shape (OIV code 220 and 223).

Table 3. Phenotypic profile of Magliocco Dolce and Brettio Nero accessions based on 45 OIV descriptors.

\begin{tabular}{|c|c|c|c|c|}
\hline OIV Code & Characteristic & Levels & Magliocco Dolce & Brettio Nero \\
\hline 001 & young shoot: aperture of tip & 1 closed, 3 half open, 5 fully open & 5 & 5 \\
\hline 003 & $\begin{array}{l}\text { young shoot: intensity of anthocyanin } \\
\text { coloration on prostrate hairs of tip }\end{array}$ & $\begin{array}{l}1 \text { none or very low, } 3 \text { low, } \\
5 \text { medium, } 7 \text { high, } 9 \text { very high }\end{array}$ & 1 & 1 \\
\hline 004 & $\begin{array}{l}\text { young shoot: density of prostrate hairs } \\
\text { on tip }\end{array}$ & $\begin{array}{l}1 \text { none or very low, } 3 \text { low, } \\
5 \text { medium, } 7 \text { high, } 9 \text { very high }\end{array}$ & 5 & 5 \\
\hline 007 & $\begin{array}{l}\text { shoot: color of dorsal side } \\
\text { of internodes }\end{array}$ & 1 green, 2 green and red, 3 red & 1 & 1 \\
\hline 008 & $\begin{array}{l}\text { shoot: color of ventral side } \\
\text { of internodes }\end{array}$ & 1 green, 2 green and red, 3 red & 1 & $1-2$ \\
\hline 016 & Shoot: number of consecutive tendrils & 1 green, 2 green and red, 3 red & 1 & 1 \\
\hline 051 & $\begin{array}{l}\text { Young leaf: color of the upper side of } \\
\text { blade (4th leaf) }\end{array}$ & $\begin{array}{l}1 \text { green, } 2 \text { yellow, } 3 \text { bronze, } \\
4 \text { copper-reddish }\end{array}$ & 1 & 1 \\
\hline 053 & $\begin{array}{l}\text { Young leaf: density of prostrate hairs } \\
\text { between main veins on lower side of } \\
\text { blade (4th leaf) }\end{array}$ & $\begin{array}{l}1 \text { none or very low, } 3 \text { low, } \\
5 \text { medium, } 7 \text { high, } 9 \text { very high }\end{array}$ & $5-7$ & $5-7$ \\
\hline 065 & Mature leaf: size of blade & $\begin{array}{l}1 \text { very small, } 3 \text {, small, } 5 \text { medium, } \\
7 \text { large, } 9 \text { very large } \\
1 \text { cordate } 2 \text { wedge-shaped }\end{array}$ & $5-7$ & $5-7$ \\
\hline 067 & Mature leaf: shape of blade & $\begin{array}{l}3 \text { pentagonal, } 4 \text { circular, } \\
5 \text { kidney-shaped }\end{array}$ & 3 & 3 \\
\hline 068 & Mature leaf: number of lobes & $\begin{array}{l}1 \text { one, } 2 \text { three, } 3 \text { five, } 4 \text { seven, } \\
5 \text { more than seven }\end{array}$ & $2-3$ & $2-3$ \\
\hline 070 & $\begin{array}{l}\text { Mature leaf: area of anthocyanin } \\
\text { coloration of main veins on upper side } \\
\text { of blade }\end{array}$ & $\begin{array}{l}1 \text { absent, } 2 \text { only at the petiolar } \\
\text { point, } 3 \text { upto the } 1 \text { st bifurcation, } \\
4 \text { up to the } 2 \text { nd bifurcation, } \\
5 \text { beyond the } 2 \text { nd bifurcation }\end{array}$ & 1 & 2 \\
\hline 072 & Mature leaf: goffering of blade & $\begin{array}{l}1 \text { absent or very weak, } 3 \text { weak, } \\
5 \text { medium, } 7 \text { strong, } 9 \text { very strong }\end{array}$ & 3 & 1 \\
\hline 074 & $\begin{array}{l}\text { Mature leaf: profile of blade in } \\
\text { cross section }\end{array}$ & $\begin{array}{l}1 \text { flat, } 2 \text { V-shaped, } 3 \text { involute, } \\
4 \text { revolute, } 5 \text { twisted }\end{array}$ & $2-5$ & 5 \\
\hline 075 & $\begin{array}{l}\text { Mature leaf: blistering of upper side } \\
\text { of blade }\end{array}$ & $\begin{array}{l}1 \text { absent or very weak, } 2 \text { weak, } \\
3 \text { medium, } 4 \text { strong, } 9 \text { very strong } \\
1 \text { both sides concave, } 2 \text { both sides } \\
\text { straight, } 3 \text { both sides convex, } 4 \text { one }\end{array}$ & $5-7$ & 5 \\
\hline 076 & Mature leaf: shape of teeth & $\begin{array}{l}\text { side concave on side convex, } \\
5 \text { mixture between both sides } \\
\text { straight and both sides convex }\end{array}$ & 5 & 5 \\
\hline 078 & $\begin{array}{l}\text { Mature leaf: length of teeth compared } \\
\text { with their width }\end{array}$ & $\begin{array}{l}1 \text { very short, } 3 \text { short, } 5 \text { medium, } \\
7 \text { long, } 9 \text { very long }\end{array}$ & 5 & $3-5$ \\
\hline 079 & $\begin{array}{l}\text { Mature leaf: degree of } \\
\text { opening/overlapping of petiole sinus }\end{array}$ & $\begin{array}{l}1 \text { very wide open, } 3 \text { open, } 5 \text { closed, } \\
7 \text { overlapped, } \\
9 \text { strongly overlapped }\end{array}$ & 5 & 7 \\
\hline 080 & $\begin{array}{l}\text { Mature leaf: shape of base of } \\
\text { petiole sinus }\end{array}$ & $\begin{array}{l}1 \text { U-shaped, } 2 \text { brace-shaped, } \\
3 \text { V-shaped }\end{array}$ & 3 & 3 \\
\hline $081-1$ & Mature leaf: teeth in the petiole sinus & 1 none, 9 present & 1 & 1 \\
\hline $081-2$ & $\begin{array}{l}\text { Mature leaf: petiole sinus base limited } \\
\text { by veins }\end{array}$ & $\begin{array}{l}1 \text { not limited, } 3 \text { on one side, } 3 \text { on } \\
\text { both sides }\end{array}$ & 1 & 1 \\
\hline $083-2$ & $\begin{array}{l}\text { Mature leaf: teeth in the upper } \\
\text { lateral sinuses }\end{array}$ & 1 none, 9 present & 1 & 1 \\
\hline 084 & $\begin{array}{l}\text { Mature leaf: density of prostrate hairs } \\
\text { between the main veins on lower side } \\
\text { of blade }\end{array}$ & $\begin{array}{l}1 \text { none or very low, } 3 \text { low, } \\
5 \text { medium, } 7 \text { high, } 9 \text { very high }\end{array}$ & $3-5$ & 5 \\
\hline
\end{tabular}


Table 3. Cont.

\begin{tabular}{|c|c|c|c|c|}
\hline OIV Code & Characteristic & Levels & Magliocco Dolce & Brettio Nero \\
\hline 087 & $\begin{array}{l}\text { Mature leaf: density of erect hairs on } \\
\text { main veins on lower side of blade }\end{array}$ & $\begin{array}{l}1 \text { none or very low, } 3 \text { low, } \\
5 \text { medium, } 7 \text { high, } 9 \text { very high }\end{array}$ & 1 & 1 \\
\hline 151 & Flower: sexual organs & $\begin{array}{l}1 \text { fully developed stamens and no } \\
\text { gynoecium, } 2 \text { fully developed } \\
\text { stamens and reduced gynoecium, } \\
3 \text { fully developed stamens and } \\
\text { fully developed gynoecium, } \\
4 \text { reflexed stamens and fully } \\
\text { developed gynoecium }\end{array}$ & 3 & 3 \\
\hline 152 & $\begin{array}{l}\text { Inflorescence: insertion of 1st } \\
\text { inflorescence }\end{array}$ & $\begin{array}{l}1 \text { up to the } 2 \text { nd node, } 23 \text { rd and } 4 \text { th } \\
\text { node, } 3 \text { from the } 5 \text { th node on }\end{array}$ & $1-2$ & $1-2$ \\
\hline 153 & $\begin{array}{l}\text { Inflorescence: number of inflorescences } \\
\text { per shoot }\end{array}$ & $\begin{array}{l}1 \text { up to } 1 \text { inflorescence, } 21,1 \text { to } 2 \\
\text { inflorescences, } 32,1 \text { to } \\
3 \text { inflorescences, } 4 \text { more than } \\
3 \text { inflorescences }\end{array}$ & 2 & 2 \\
\hline 202 & Bunch: length (peduncle excluded) & $\begin{array}{l}1 \text { very short, } 3 \text { short, } 5 \text { medium, } \\
7 \text { long, } 9 \text { very long. }\end{array}$ & $3-5$ & $5-7$ \\
\hline 204 & Bunch: density & $\begin{array}{l}1 \text { very loose, } 3 \text { loose, } 5 \text { medium, } \\
7 \text { dense, } 9 \text { very dense }\end{array}$ & $5-7$ & $5-7$ \\
\hline 206 & $\begin{array}{l}\text { Bunch: length of peduncle of } \\
\text { primary bunch }\end{array}$ & $\begin{array}{l}1 \text { very short, } 3 \text { short, } 5 \text { medium, } \\
7 \text { long, } 9 \text { very long }\end{array}$ & $3-5$ & $3-5$ \\
\hline 208 & Bunch: shape & $\begin{array}{l}1 \text { cylindrical, } 2 \text { conical, } \\
3 \text { funnel shaped }\end{array}$ & 2 & 2 \\
\hline 209 & $\begin{array}{l}\text { Bunch: number of wings of the } \\
\text { primary bunch }\end{array}$ & $\begin{array}{l}1 \text { absent, } 2 \text { 1-2 wings, } 33-4 \text { wings, } \\
45-6 \text { wings, } 5 \text { more than } 6 \text { wings }\end{array}$ & $1-2$ & $1-2$ \\
\hline 220 & Berry: length & $\begin{array}{l}1 \text { very short, } 3 \text { short, } 5 \text { medium, } \\
7 \text { long, } 9 \text { very long } \\
1 \text { obloid, } 2 \text { globose, } 3 \text { broad } \\
\text { ellipsoid, } 4 \text { narrow ellipsoid, }\end{array}$ & 3 & $5-7$ \\
\hline 223 & Berry: shape & $\begin{array}{l}5 \text { cylindrical, } 6 \text { obtuse ovoid, } \\
7 \text { ovoid, } 8 \text { obovoid, } 9 \text { horn shaped, } \\
10 \text { finger shaped }\end{array}$ & 2 & 3 \\
\hline 225 & Berry: color of skin & $\begin{array}{l}1 \text { green yellow, } 2 \text { rose, } 3 \text { red, } 4 \text { grey, } \\
5 \text { dark red violet, } 6 \text { blue black }\end{array}$ & 6 & 6 \\
\hline 228 & Berry: thickness of skin & $\begin{array}{l}1 \text { very thin, } 3 \text { thin, } 5 \text { medium, } \\
7 \text { thick, } 9 \text { very thick }\end{array}$ & 7 & 7 \\
\hline 235 & Berry: firmness of flesh & 1 soft, 2 slightly firm, 3 very firm & 2 & 2 \\
\hline 236 & Berry: particularity of flavor & $\begin{array}{l}1 \text { none, } 2 \text { muscat, } 3 \text { foxy, } \\
4 \text { herbaceous, } 5 \text { other flavor }\end{array}$ & 1 & 1 \\
\hline 241 & Berry: formation of seeds & 1 none, 2 rudimentary, 3 complete & 3 & 3 \\
\hline 351 & Vigor of shoot growth & $\begin{array}{l}1 \text { very weak, } 3 \text { weak, } 5 \text { medium, } \\
7 \text { strong, } 9 \text { very strong }\end{array}$ & 5 & 5 \\
\hline 352 & Growth of axillary shoots & $\begin{array}{l}1 \text { absent or very weak, } 3 \text { weak, } \\
5 \text { medium, } 7 \text { strong, } 9 \text { very strong }\end{array}$ & 5 & 5 \\
\hline 353 & Length of internodes & $\begin{array}{l}1 \text { very short, } 3 \text { short, } 5 \text { medium, } \\
7 \text { long, } 9 \text { very long }\end{array}$ & $3-5$ & 3 \\
\hline 502 & Bunch: weight of a single bunch & $\begin{array}{l}1 \text { very low, } 3 \text { low, } 5 \text { medium, } \\
7 \text { high, } 9 \text { very high }\end{array}$ & 3 & 3 \\
\hline 503 & Berry: single berry weight & $\begin{array}{l}1 \text { very low, } 3 \text { low, } 5 \text { medium, } \\
7 \text { high, } 9 \text { very high }\end{array}$ & $1-3$ & $1-3$ \\
\hline 504 & Yield per $\mathrm{m}^{2}$ & $\begin{array}{l}1 \text { very low, } 3 \text { low, } 5 \text { medium, } \\
7 \text { high, } 9 \text { very high }\end{array}$ & 5 & 5 \\
\hline
\end{tabular}

Ripening curves referred to sugar concentration, $\mathrm{pH}$, and total acidity were built for the two varieties, considering 4 distinct stages of ripening (from E-L 35 to E-L 38). In both varieties, during veraison sugar concentration increases rapidly, also $\mathrm{pH}$ increases as total acidity decreases. Both, Brettio Nero and Magliocco Dolce exhibited similar profiles reaching approximately the same value of sugar concentration and $\mathrm{pH}$ at maturity (Figure 2). The principal compounds responsible for berry phenolic profile and representing some of the principal factors affecting red wine quality were also measured in the two varieties (Figure 3). 

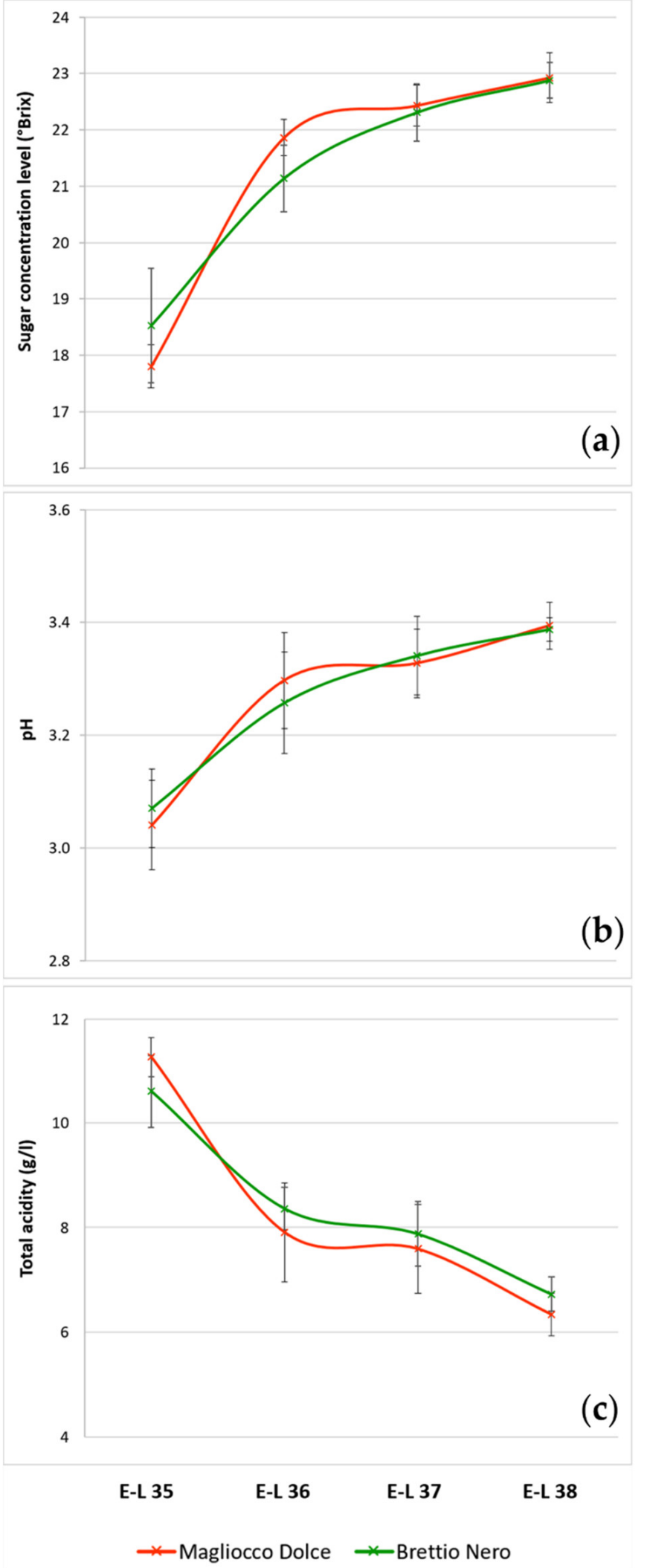

Figure 2. Changes in sugar concentration (a), $\mathrm{pH}(\mathbf{b})$, and total acidity (c) during veraison in Magliocco Dolce and Brettio Nero varieties. Samples were collected for three seasons (2016-2018) at 4 distinct time points: beginning of veraison (E-L 35), middle veraison (E-L 36), end of veraison (E-L 37), and maturity (E-L 38). Standard unpaired Student's $t$-test was used for comparison of two varieties. 


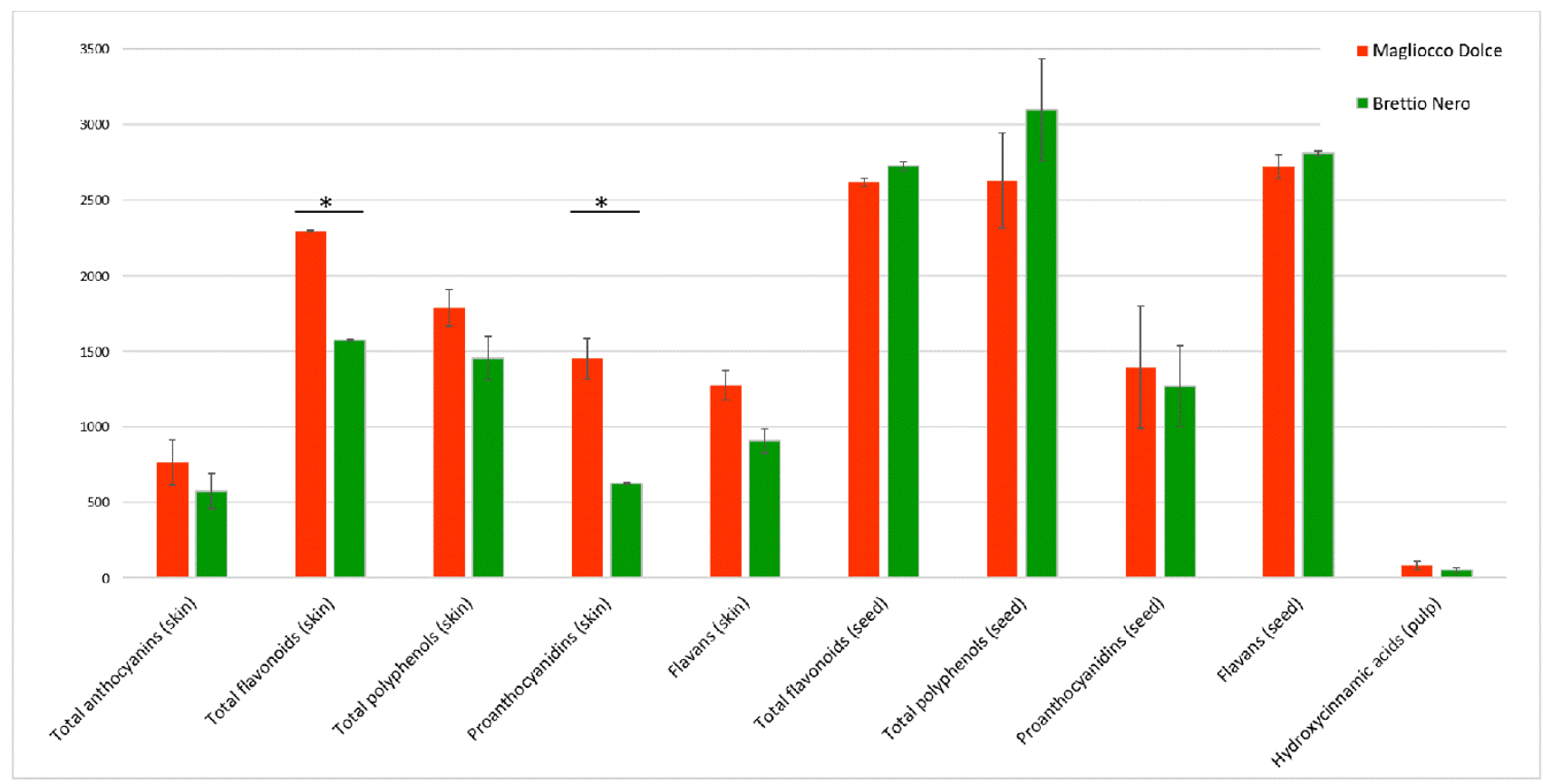

Figure 3. Polyphenols content measured in berry of Magliocco Dolce and Brettio Nero at maturity. Data were collected for two seasons (2016-2017). Standard unpaired Student's $t$-test was used for comparison of two varieties, ${ }^{*} p<0.05$.

In general, Magliocco Dolce showed higher levels of polyphenolic compounds in the skin compared to Brettio Nero, in particular, a significant difference was observed for total flavonoids and proanthocyanidins $(p<0.05)$, whereas the levels of polyphenolic compounds were comparable between the two varieties in the seed. Finally, hydroxycinnamic acids in berry pulp were slightly lower in Brettio Nero compared to Magliocco Dolce.

\subsection{Oenological Parameters and Wine Sensory Analysis}

A total of 20 oenological parameters were analyzed in the two monovarietal wines obtained from Magliocco Dolce and Brettio Nero. Both wines showed similar values for all parameters with only two exceptions of ashes, lower in Brettio Nero compared to Magliocco Dolce, and malic acid, higher in Brettio Nero compared to Magliocco Dolce (Table 4).

In general, the polyphenols content (except flavans) showed to be higher in Magliocco Dolce wine than Brettio Nero wine, according to polyphenols content observed in berry skin of the two varieties. Although, it should also be noted that the standard deviation of data (especially the one related to total proanthocyanidins and flavans) showed very high values, indicating a high variation of data in analyzed replicates (Table 4).

The wine sensory evaluation of the two monovarietal wines, performed on 24 sensorial parameters, indicated a higher limpidity and color intensity of Brettio Nero wine compared to Magliocco Dolce one. In general, Brettio Nero wine showed to be more aromatic than Magliocco Dolce, while no differences were observed in smell intensity, persistency, and quality. The $50 \%$ of tasters indicated a much higher acidity and tasteness of Brettio Nero wine, while no significant differences were observed in other flavor features of the two wines (Figure 4). 
Table 4. Chemical parameters and polyphenols content measured in Magliocco Dolce and Brettio Nero monovarietal wines. Analysis was performed for two seasons (2016-2017). Standard unpaired Student's $t$-test was used for comparison of two varieties, ${ }^{*} p<0.05$.

\begin{tabular}{ccc}
\hline Parameter & Magliocco Dolce & Brettio Nero \\
\hline Alcoholic degree $(\%, \pm v / v)$ & $14.02 \pm 0.59$ & $13.37 \pm 0.64$ \\
Total acidity (g/L) & $6.55 \pm 0.32$ & $6.51 \pm 0.52$ \\
pH & $3.48 \pm 0.17$ & $3.52 \pm 0.16$ \\
Density $\left(20^{\circ} / 20^{\circ}\right)$ & $1.04 \pm 0.07$ & $1.05 \pm 0.07$ \\
Total dry extract (g/L) & $32.24 \pm 1.63$ & $28.67 \pm 0.27$ \\
Volatile acidity (g/L) & $0.5 \pm 0.03$ & $0.39 \pm 0.13$ \\
Ashes (g/L) & $3.15 \pm 0.01$ & $2.95 \pm 0.06^{*}$ \\
Malic acid (g/L) & $3.11 \pm 0.06$ & $3.73 \pm 0.16^{*}$ \\
Tartaric acid (g/L) & $3.28 \pm 1.17$ & $2.93 \pm 1.16$ \\
Citric acid (g/L) & $0.1 \pm 0.04$ & $0.16 \pm 0.01$ \\
Glycerol (g/L) & $9.68 \pm 0.48$ & $8.95 \pm 0.82$ \\
Potassium (g/L) & $1.39 \pm 0.35$ & $1.44 \pm 0.27$ \\
Sulfates (g/L) & $0.42 \pm 0.13$ & $0.51 \pm 0.07$ \\
Color intensity & $8.82 \pm 0.69$ & $7.23 \pm 1.74$ \\
Color tonality & $0.85 \pm 0.32$ & $0.92 \pm 0.42$ \\
Total anthocyanins (mg/L) & $171.81 \pm 21.15$ & $82.87 \pm 31.44$ \\
Total flavonoids (mg/L) & $973.12 \pm 314.93$ & $715.44 \pm 75.37$ \\
Total polyphenols (mg/ L) & $2207.23 \pm 309.91$ & $1759.63 \pm 505.08$ \\
Proanthocyanidins (mg/ L) & $2370.49 \pm 1280.70$ & $1709.40 \pm 915.09$ \\
Flavans (mg/L) & $471.13 \pm 227.00$ & $756.52 \pm 402.89$
\end{tabular}

(a)

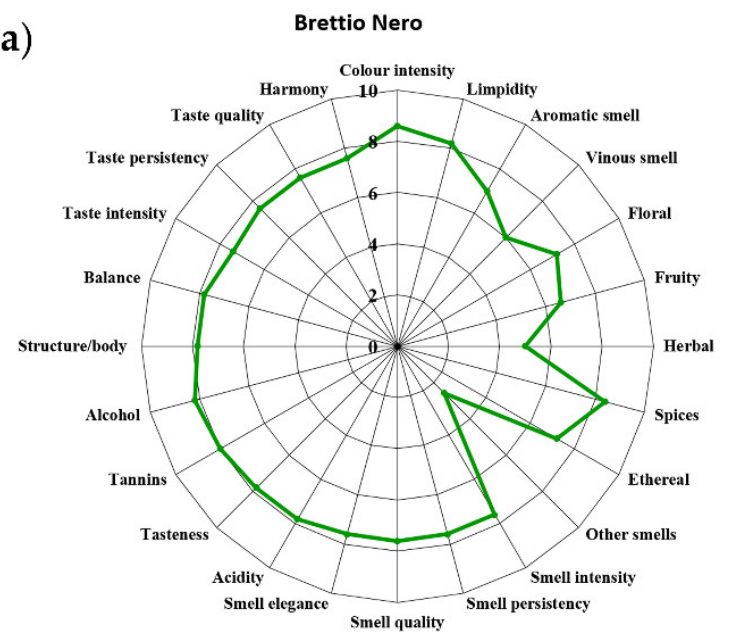

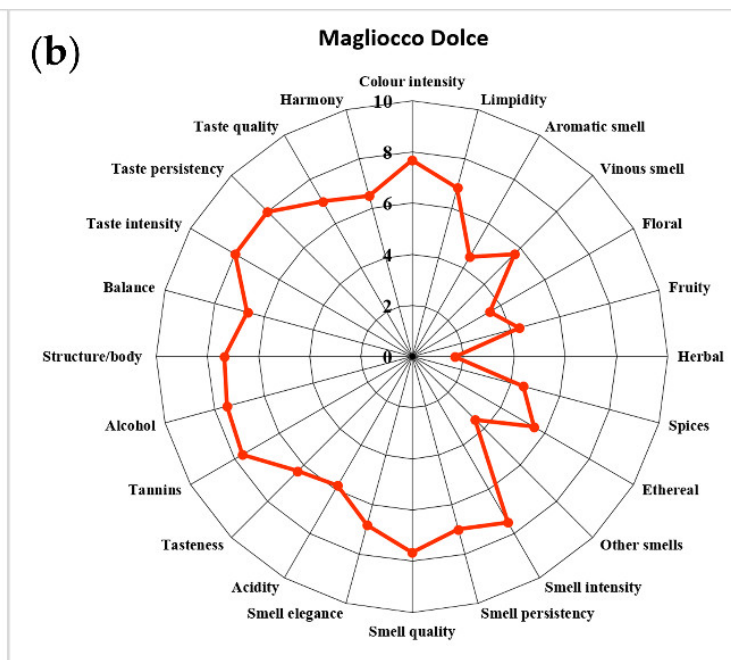

Figure 4. Brettio Nero (a) and Magliocco Dolce (b) monovarietal wine sensorial profiles based on 24 parameters evaluated by consumer volunteers.

\section{Discussion}

The increase in Calabrian wine production along with the growing interest shown by consumers towards local and peculiar Italian products make crucially important the characterization of local grapevine varieties along with the clarification of naming of these cultivars since a general variety name confusion is rather widespread. Our work has covered a series of genetic, viticultural, and oenological analyses in order to unequivocally characterize two widespread Calabrian grapevine varieties: Magliocco Dolce and Brettio Nero.

ARSAC-authenticated plants of the varieties Magliocco Dolce and Brettio Nero were genotyped with 12 SSR markers. The obtained molecular profiles were compared with that of 26 popular Calabrian accessions and 36 Italian varieties. Moreover, a comparison with 
some of the most spread Italian cultivars available in three different molecular databases was also made. The dendrogram built through the unweighted neighbor-joining method highlighted the presence of three principal groups (Figure 1), with most of the Calabrian accessions clustered together in the sub-cluster I-a1 and the cluster I-b. Mantonico Nero accession sampled in Calabria resulted to be genetically identical to the ARSAC-authenticated Brettio Nero confirming to be a specific genotype different from any other accession included Mantonico Bianco. Despite the general practice to use the same varietal name for berry colors variant, derived from a somatic mutation affecting fruit color [8,9], in the case of the name Mantonico this could not be used to indicate the white "Bianco" and black "Nero" variants. Thus, the new name Brettio Nero was proposed instead of Mantonico Nero for the registration of this variety into the Italian National Registry of Grape Varieties. The misuse of the same name followed by "Bianco" and "Nero" designation to indicate different varieties is not uncommon. Indeed, Greco Bianco showed a different molecular profile compared to Greco Nero and the same situation is observed for Bombino Bianco and Bombino Nero (Figure 1).

ARSAC-authenticated Magliocco Dolce (cluster I-b) showed to be completely different from ARSAC-authenticated Greco Nero (sub-cluster I-a1) which, thus, cannot be considered synonymous of Magliocco Dolce [2]. In the same way, it showed a different molecular profile from that of Notardomenico retrieved from INRGV, excluding also, in this case, the hypothesis that Magliocco Dolce and Notardomenico are synonymous [11]. By contrast, the names Lagrima Nera, Arvino, and Magliocco Dolce were confirmed as synonymies [31]. The genetic analysis showed different molecular profiles for Magliocco Dolce and Magliocco Canino and genetic similarity of the latter with the variety Perricone, in accord with Pellerone et al. [29]. Based on our results, we can sustain that Magliocco Dolce and Brettio Nero represent two unique varieties not matching with any other registered Calabrian variety. Moreover, we highlighted the necessity to define the new name Brettio Nero instead of Mantonico Nero in order to clearly distinguish this cultivar from the Mantonico Bianco variety.

For a long time, ampelography was the only methodology used to identify grape varieties [50,51]. Today, despite the introduction of more reliable genetic methods, it is still fundamental for the identification and description of grape cultivars. We used 45 OIV descriptors to morphologically describe Magliocco Dolce and Brettio Nero varieties (Table 3), including all that required for registration of a new variety into the Italian National Registry of Grape Varieties. Magliocco Dolce and Brettio Nero varieties were investigated also for physico-chemical parameters of berry, including the content of some classes of polyphenols. Grape berries are a non-climacteric fruit, and the ripening process involves numerous physiological and metabolic activities occurring during the whole veraison phase till the berry reaches maturity making them suitable for vinification. These changes make the ripening process a determining factor in the quality of grapes and wines [52]. For both Magliocco Dolce and Brettio Nero varieties, several chemical parameters were measured in berries at different ripening stages. The ripening curves showed a sigmoidal trend with a rapid increase of sugar concentration reaching the highest value at maturity (about $23^{\circ}$ Brix for both varieties). Simultaneously, total acidity decreases inducing an increase of $\mathrm{pH}$ from about 3.1 at the beginning of veraison to about 3.4 at maturity (Figure 2).

The evaluation of the sugar content and acidity level alone does not fully express the real oenological potential of a grape accession. The knowledge of the polyphenolic profile of grapes allows careful planning of the winemaking process and the exploitation of the full potentiality of a variety [53]. In red wines, the polyphenolic content of berry at maturity (grape phenolic maturity) is one of the major factors affecting quality. Most of the wine's sensory characteristics, such as color, astringency, and bitterness, are directly associated with the profile of anthocyanins and proanthocyanidins [54,55]. We evaluated the grape phenolic maturity of Magliocco Dolce and Brettio Nero through the measurement of principal phenolic compounds. Our results showed to be highly variable, being more affected by 
climatic conditions and viticulture practices than the grape cultivar. Nevertheless, they are in line with findings obtained by other authors $[33,56,57]$.

Wine quality and flavor are affected by several factors including the physico-chemical characteristics of berries at harvesting and the operating conditions adopted during grape maceration that can strongly influence the amount of extracted phenols. In order to evaluate the effects of berry composition on the content and flavor of wine during the winemaking process, 20 oenological parameters were checked in Magliocco Dolce and Brettio Nero monovarietal wines. Moreover, a sensorial analysis based on the detection of 24 parameters was performed by six consumer volunteers. The two wines reached the minimum percentage for the volume of alcohol established by law ( $>9 \%$ volume; Council Regulation (EC) No 1234/2007) [47] and a high alcoholic sensation in the sensory analysis was perceived. Acidity, which plays an important role in wine tasting, as it confers crispness and freshness to the wine, reached similar levels in the two varieties. Both wines showed normal values of total acidity (between 5 e $8 \mathrm{~g} / \mathrm{L}$ ) and $\mathrm{pH}$ (between 3 and 3.7) and low volatile acidity $(<1 \mathrm{~g} / \mathrm{L})$ [58]. Although both wines showed a comparable level of acidity (Table 4), acidity was perceived more in Brettio Nero wine compared to Magliocco Dolce. Color intensity and tonality, which are mostly determined by anthocyanin content [59], showed, as expected, very high values; in particular, color intensity showed to be higher in Magliocco Dolce wine compared to Brettio Nero wine, according to the higher content of anthocyanins in berry skin; nevertheless, Brettio Nero wine was judged more intensely colored by consumers. Phenolic compounds play an important antioxidant activity in wines, especially in red ones [60]. The levels of polyphenols compounds found in the two monovarietal wines are comparable with that observed commonly in red wines [61]. In general, a higher polyphenols content was observed in Magliocco Dolce wine compared to Brettio Nero wine, as well as a higher polyphenols content was observed in Magliocco Dolce berries. Regarding the sensorial analysis, in general, both wines were judged as harmonious and tasty. The wine produced with Brettio Nero variety presented an intense floral and fruity smell while Magliocco Dolce wine was judged slightly perfumed.

\section{Conclusions}

In our study, we deeply characterized two Calabrian varieties-Magliocco Dolce and Brettio Nero-with the purpose to valorize them and boost their use in wine production. The genetic analysis allowed us to verify that they are unique and distinct accession and to define a genetic profile useful for molecular traceability purposes. The morphological evaluation highlighted the peculiar characteristics of Magliocco Dolce and Brettio Nero allowing their discrimination from any other Calabrian variety. Finally, the chemical analysis of berry and the evaluation of oenological properties of Magliocco Dolce and Brettio Nero demonstrated the suitability of these varieties in high-quality wine production.

In the future, the characterization of other Calabrian grapevine samples following the same multidisciplinary approach will allow the valorization of local and peculiar accessions and their registration in the Italian National Registry of Grape Varieties. This will contribute to promote the quality and value of the wine produced with these new varieties and highlight the potential of Calabria region in the wine sector.

Supplementary Materials: The following are available online at https: / www.mdpi.com/article/10 .3390 /agronomy11081538/s1, Table S1: List of synonyms found in our study and comparison with synonyms recognized by the Italian National Registry of Grape Varieties, Table S2: Molecular profile obtained for the ARSAC-authenticated accessions and comparison with the profiles contained in the Vitis International Variety Catalogue (VIVC).

Author Contributions: Conceptualization, V.F., V.R., V.N.S. and C.M.; Data curation, V.R. and P.V.; Formal analysis, V.F.; Methodology, V.F., V.R., M.A.S., P.V. and C.P.; Project administration, V.N.S., P.L.N. and C.M.; Resources, M.F. and F.P.; Software, V.F., M.A.S. and M.M.M.; Supervision, C.M.; Writing-original draft, V.F.; Writing—review and editing, V.F., V.R., M.M.M. and C.M. All authors have read and agreed to the published version of the manuscript. 
Funding: This research was funded by CAMERA DI COMMERCIO DI COSENZA, Deliberazione $\mathrm{n}$. 28 del 19/04/2016. Valentina Fanelli was supported by MIUR-PON Ricerca e Innovazione 2014-2020 (project AIM1809249-attività 2, linea 1).

Data Availability Statement: All data are included in the manuscript.

Acknowledgments: The authors would like to thank Marcello Bruno and Claudio Fuoco from Agenzia Regionale per lo Sviluppo dell'Agricoltura in Calabria (ARSAC) for their help in sampling plant material.

Conflicts of Interest: The authors declare no conflict of interest.

\section{References}

1. De Bonis, M. Terra D'Uve Vini e Vitigni in Calabria Dall'antichità All'Ottocento: Notizie, Curiosità, Immagini; Le Nuvole: Cosenza, Italy, 2003.

2. Sunseri, F.; Lupini, A.; Mauceri, A.; de Lorenzis, G.; Araniti, F.; Brancadoro, L.F.; Dattola, A.; Gullo, G.; Zappia, R.; Mercatiet, F. Single nucleotide polymorphism profiles reveal an admixture genetic structure of grapevine germplasm from Calabria, Italy, uncovering its key role for the diversification of cultivars in the Mediterranean Basin. Aust. J. Grape Wine Res. 2018, 24, 345-359. [CrossRef]

3. De Lorenzis, G.; Mercati, F.; Bergamini, C.; Cardone, M.F.; Lupini, A.; Mauceri, A.; Caputo, A.R.; Abbate, L.; Barbagallo, M.G.; Antonacci, D.; et al. SNP genotyping elucidates the genetic diversity of Magna Graecia grapevine germplasm and its historical origin and dissemination. BMC Plant Biol. 2019, 20, 7. [CrossRef]

4. Mateus, N.; Proença, S.; Ribeiro, P.; Machado, J.M.; De Freitas, V. Grape and wine polyphenolic composition of red Vitis vinifera varieties concerning vineyard altitude. Cienc. Y Tecnol. Aliment. 2001, 3, 102-110. [CrossRef]

5. ISTAT. Available online: http:/ / www.istat.it (accessed on 30 March 2021).

6. Ministerial, D. October, 18: Disciplinare di Produzione dei vini a Denominazione di Origine Controllata "Terre di Cosenza", Approvato con D.M. 18.10.2011, Gazzetta Ufficiale n. 256-03.11.2011. Modificato con DM 23.11.2015, Pubblicato sul sito Ufficiale del Mipaaf Sezione Prodotti DOP e IGP - Vini DOP e IGP. Available online: http:/ /www.politicheagricole.it (accessed on 12 March 2021).

7. Robinson, J.; Harding, J.; Vouillamoz, J. Wine Grapes: A Complete Guide to 1368 Vine Varieties, including Their Origins and Flavours; HarperCollins: New York, NY, USA, 2012.

8. Vezzulli, S.; Leonardelli, L.; Malossini, U.; Stefanini, M.; Velasco, R.; Moser, C. Pinot blanc and Pinot gris arose as independent somatic mutations of Pinot noir. J. Exp. Bot. 2012, 63, 6359-6369. [CrossRef]

9. Ferreira, V.; Matus, J.T.; Pinto-Carnide, O.; Carrasco, D.; Arroyo-García, R.; Castro, I. Genetic analysis of a white-to-red berry skin color reversion and its transcriptomic and metabolic consequences in grapevine (Vitis vinifera cv. 'Moscatel Galego'). BMC Genom. 2019, 20, 952. [CrossRef] [PubMed]

10. Crespan, M.; Storchi, P.; Migliaro, D. Grapevine cultivar Mantonico bianco is the second parent of the Sicilian Catarratto. Am. J. Enol. Vitic. 2017, 68, 258-262. [CrossRef]

11. Schneider, A.; Raimondi, S.; Pirolo, C.S.; Torello Marinoni, D.T.; Ruffa, P.; Venerito, P.; La Notte, P. Genetic characterization of grape cultivars from Apulia (Southern Italy) and synonymies in other Mediterranean regions. Am. J. Enol. Vitic. 2014, 65, 244-249. [CrossRef]

12. Raimondi, S.; Ruffa, P.; De Lorenzis, G.; Imazio, S.; Fiori, S.; Failla, O.; Schneider, A. Detection of grapevine synonyms in Lombardy and Piedmont regions (northern Italy). Vitis 2015, 54, 31-36.

13. Miazzi, M.M.; D’Agostino, N.; Gadaleta, S.; Di Rienzo, V.; Fanelli, V.; Sabetta, W.; Montemurro, C.; Taranto, F. Genotypingby-sequencing-derived single-nucleotide polymorphism catalog from a grapevine (Vitis vinifera L.) germplasm collection that includes the most representative Apulian autochthonous cultivars. Acta Hortic. 2019, 1248, 69-76. [CrossRef]

14. Jaillon, O.; Aury, J.M.; Noel, B.; Policriti, A.; Clepet, C.; Casagrande, A.; Choisne, N.; Aubourg, S.; Vitulo, N.; Jubin, C.; et al. The grapevine genome sequence suggests ancestral hexaploidization in major angiosperm phyla. Nature 2007, 449, 463-467.

15. Velasco, R.; Zharkikh, A.; Troggio, M.; Cartwright, D.A.; Cestaro, A.; Pruss, D.; Pindo, M.; FitzGerald, L.M.; Vezzulli, S.; Reid, J.; et al. A high quality draft consensus sequence of the genome of a heterozygous grapevine variety. PLoS ONE 2007, 2, e1326. [CrossRef] [PubMed]

16. Marrano, A.; Micheletti, D.; Lorenzi, S.; Neale, D.; Grando, M.S. Genomic signatures of different adaptations to environmental stimuli between wild and cultivated Vitis vinifera L. Hortic. Res. 2018, 5, 34. [CrossRef] [PubMed]

17. Guo, D.L.; Zhao, H.L.; Li, Q.; Zhang, G.H.; Jiang, J.F.; Liu, C.H.; Yu, Y.H. Genome-wide association study of berry-related traits in grape [Vitis vinifera L.] based on genotyping-by-sequencing markers. Hortic. Res. 2019, 6, 11. [CrossRef] [PubMed]

18. Delfino, P.; Zenoni, S.; Imanifard, Z.; Tornielli, G.B.; Bellin, D. Selection of candidate genes controlling veraison time in grapevine through integration of meta-QTL and transcriptomic data. BMC Genom. 2019, 20, 739. [CrossRef] [PubMed]

19. Bergamini, C.; Cardone, M.F.; Anaclerio, A.; Perniola, R.; Pichierri, A.; Genghi, R.; Alba, V.; Forleo, L.R.; Caputo, A.R.; Montemurro, C.; et al. Validation assay of p3_VvAGL11 marker in a wide range of genetic background for early selection of stenospermocarpy in Vitis vinifera L. Mol. Biotechnol. 2013, 54, 1021-1030. [CrossRef] 
20. Zini, E.; Dolzani, C.; Stefanini, M.; Gratl, V.; Bettinelli, P.; Nicolini, D.; Betta, G.; Dorigatti, C.; Velasco, R.; Letschka, T.; et al. R-loci arrangement versus downy and powdery mildew resistance level: A Vitis hybrid survey. Int. J. Mol. Sci. 2019, $20,3526$. [CrossRef]

21. Massonnet, M.; Fasoli, M.; Tornielli, G.B.; Altieri, M.; Sandri, M.; Zuccolotto, P.; Paci, P.; Gardiman, M.; Zenoni, S.; Pezzotti, M. Ripening transcriptomic program in red and white grapevine varieties correlates with berry skin anthocyanin accumulation. Plant Physiol. 2017, 174, 2376-2396. [CrossRef]

22. Volpicella, M.; Leoni, C.; Costanza, A.; Fanizza, I.; Placido, A.; Ceci, L.R. Genome walking by Next Generation Sequencing approaches. Biology 2012, 1, 495-507. [CrossRef]

23. Galet, P.; Morton, L.T.; Adams, L.D. A Practical Ampelography: Grapevine Identification; Comstock: New York, NY, USA, 1979.

24. OIV. Second Edition of the OIV Descriptor List for Grape Varieties and Vitis Species. Paris, France-International Plant Genetic Resources Institute, Rome. 2009. Available online: http:/ / www.oiv.org (accessed on 20 February 2021).

25. This, P.; Lacombe, T.; Thomas, M. Historical origins and genetic diversity of wine grapes. Trends Genet. 2006, 22, 511-519. [CrossRef]

26. Tautz, D. Hypervariability of simple sequences as a general source for polymorphic DNA markers. Nucleic Acids Res. 1989, 17, 6463-6471. [CrossRef]

27. Kamiloglu, S. Authenticity and traceability in beverages. Food Chem. 2019, 277, 12-24. [CrossRef] [PubMed]

28. Fanelli, V.; Mascio, I.; Miazzi, M.M.; Savoia, M.A.; De Giovanni, C.; Montemurro, C. Molecular Approaches to Agri-Food Traceability and Authentication: An Updated Review. Foods 2021, 10, 1644. [CrossRef]

29. Pellerone, F.I.; Edwards, K.J.; Thomas, M.R. Grapevine microsatellite repeats: Isolation, characterisation and use for genotyping of grape germplasm from Southern Italy. Vitis 2001, 40, 179-186.

30. Gristina, A.S.; De Michele, R.; Garfi, G.; La Mantia, T.; Fontana, I.; Spinelli, P.; Motisi, A.; Carimi, F. Urgent need for preservation of grapevine (Vitis vinifera L. subsp. vinifera) germplasm from small circum-Sicilian islands as revealed by SSR markers and traditional use investigations. Genet. Resour. Crop Evol. 2016, 64, 1395-1415. [CrossRef]

31. Fanelli, V.; Savoia, M.A.; Gadaleta, S.; Piarulli, L.; Montemurro, C.; La Notte, P.; Miazzi, M.M.; Bruno, M.; Falbo, M.; Petrillo, F.; et al. Molecular characterization of wine grape cultivars from Calabria. Acta Hortic. 2019, 1248, 281-286. [CrossRef]

32. Italian National Registry of Grape Varieties. Available online: http:/ / catalogoviti.politicheagricole.it/catalogo.php (accessed on 26 February 2021).

33. Torchio, F.; Cagnasso, E.; Gerbi, V.; Rolle, L. Mechanical properties, phenolic composition and extractability indices of Barbera grapes of different soluble solids contents from several growing areas. Anal. Chim. Acta 2010, 660, 183-189. [CrossRef]

34. Fanelli, V.; Volpicella, M.; Giampetruzzi, A.; Saldarelli, P.; Leoni, C.; Ceci, L.R.; Di Rienzo, V.; Venerito, P.; Taranto, F.; Giannini, P.; et al. Valorization of autochthonous Apulian grapevine cultivars for spumante production. Acta Hortic. 2019, 1248, 457-462. [CrossRef]

35. Pastore, C.; Fontana, M.; Raimondi, S.; Ruffa, P.; Filippetti, I.; Schneider, A. Genetic characterization of grapevine varieties from Emilia-Romagna (Northern Italy) discloses unexplored genetic resources. Am. J. Enol. Vitic. 2020, 71, 334-343. [CrossRef]

36. Italian Vitis Database. Available online: https:/ / vitisdb.it/ (accessed on 26 February 2021).

37. European Vitis Database. Available online: http:/ / www.eu-vitis.de/index.php (accessed on 26 February 2021).

38. Spadoni, A.; Sion, S.; Gadaleta, S.; Savoia, M.; Piarulli, L.; Fanelli, V.; Di Rienzo, V.; Taranto, F.; Miazzi, M.M.; Montemurro, C.; et al. A simple and rapid method for genomic DNA extraction and microsatellite analysis in tree plants. J. Agric. Sci. Technol. 2019, 21, 1215-1226.

39. Thomas, M.R.; Cain, P.; Scott, N.S. DNA typing of grapevines: A universal methodology and database for describing cultivars and evaluating genetic relatedness. Plant Mol. Biol. 1994, 25, 939-949. [CrossRef]

40. Bowers, J.E.; Dangl, G.S.; Vignani, R.; Meredith, C.P. Isolation and characterization of new polymorphic simple sequence repeat loci in grape (Vitis vinifera L.). Genome 1996, 39, 628-633. [CrossRef] [PubMed]

41. Bowers, J.E.; Dangl, G.S.; Meredith, C.P. Development and characterization of additional microsatellite DNA markers for grape. Am. J. Enol. Vitic. 1999, 50, 243-246.

42. Sefc, K.M.; Regner, F.; Turetschek, E.; Glössl, J.; Steinkellner, H. Identification of microsatellite sequences in Vitis riparia and their applicability for genotyping of different Vitis species. Genome 1999, 42, 367-373. [CrossRef] [PubMed]

43. Peakall, R.O.D.; Smouse, P.E. GENALEX 6: Genetic analysis in Excel. Population genetic software for teaching and research. Mol. Ecol. Notes 2006, 6, 288-295.

44. Kalinowski, S.T.; Taper, M.L.; Marshall, T.C. Revising how the computer program Cervus accommodates genotyping error increases success in paternity assignment. Mol. Ecol. 2007, 16, 1099-1106. [CrossRef]

45. DARwin6. Available online: https:/ / darwin.cirad.fr/ (accessed on 12 March 2021).

46. Di Stefano, R.; Cravero, M.C. Metodi per lo studio dei polifenoli dell'uva. Riv. Di Vitic. E Di Enol. 1991, 44, 37-45.

47. Official Journal of the European Union. Council Regulation (EC) No 1234/2007 of 22 October 2007 Establishing a Common Organisation of Agricultural Markets and on Specific Provisions for Certain Agricultural Products (Single CMO Regulation). Available online: https:/ / eur-lex.europa.eu/ (accessed on 26 February 2021).

48. Di Stefano, R.; Cravero, M.C.; Gentilini, N. Metodi per lo studio dei polifenoli dei vini. L'Enotecnico 1989, $25,83-89$.

49. Vitis International Variety Catalogue. Available online: https:/ /www.vivc.de/ (accessed on 23 July 2021).

50. Alleweldt, G.; Dettweıler, E. Ampelographic studies to characterize grapevine varieties. Vignevini 1986, 13, 56-59. 
51. Santıago, J.L.; Boso, S.; del Carmen Martínez, M.; Pınto-Carnıde, O.; Ortız, J.M. Ampelographic comparison of grape cultivars (Vitis vinifera L.) grown in Northwestern Spain and Northern Portugal. Am. J. Enol. Vitic. 2005, 56, 287-290.

52. Coombe, B.G.; McCarthy, M.G. Dynamics of grape berry growth and physiology of ripening. Aust. J. Grape Wine Res. 2000, 6, 131-135. [CrossRef]

53. González-Neves, G.; Charamelo, D.; Balado, J.; Barreiro, L.; Bochicchio, R.; Gatto, G.; Gil, G.; Tessore, A.; Carbonneau, A.; Moutounet, M. Phenolic potential of Tannat, Cabernet-Sauvignon and Merlot grapes and their correspondence with wine composition. Anal. Chim. Acta 2004, 513, 191-196. [CrossRef]

54. Noble, A.C. Bitterness and astringency in wine. In Bitterness in Foods and Beverages, Development in Food Science; Rouseff, R.L., Ed.; Elsevier: New York, NY, USA, 1990; pp. 145-158.

55. Vidal, S.; Francis, L.; Guyot, S.; Marnet, N.; Kwiatkowski, M.; Gawel, R.; Cheynier, V.; Waterset, E.J. The mouth-feel properties of grape and apple proanthocyanidins in a wine-like medium. J. Sci. Food Agric. 2003, 83, 564-573. [CrossRef]

56. Mattivi, F.; Guzzon, R.; Vrhovsek, U.; Stefanini, M.; Velasco, R. Metabolite profiling of grape: Flavonols and anthocyanins. J. Agric. Food Chem. 2006, 54, 7692-7702. [CrossRef]

57. Pantelić, M.M.; Dabić Zagorac, D.Č.; Davidović, S.M.; Todić, S.R.; Bešlić, Z.S.; Gašić, U.M.; Tešić, Z.L.; Natić, M.M. Identification and quantification of phenolic compounds in berry skin, pulp, and seeds in 13 grapevine varieties grown in Serbia. Food Chem. 2016, 211, 243-252. [CrossRef] [PubMed]

58. Waterhouse, A.L.; Sacks, G.L.; Jeffery, D.W. Understanding Wine Chemistry, 1st ed.; Wiley: Hoboken, NJ, USA, 2016.

59. He, F.; Liang, N.N.; Mu, L.; Pan, Q.H.; Wang, J.; Reeves, M.J.; Duan, C.Q. Anthocyanins and Their Variation in Red Wines I. Monomeric Anthocyanins and Their Color Expression. Molecules 2012, 17, 1571-1601.

60. Wang, H.; Cao, G.; Prior, R.L. Total antioxidant capacity of fruits. J. Agric. Food Chem. 1996, 44, 701-705. [CrossRef]

61. Ivanova, V.; Dörnyei, Á.; Márk, L.; Vojnoski, B.; Stafilov, T.; Stefova, M.; Kilár, F. Polyphenolic content of Vranec wines produced by different vinification conditions. Food Chem. 2011, 124, 316-325. [CrossRef] 